\title{
Water Quality Measurement and Filtering Tools Using Arduino Uno, PH Sensor and TDS Meter Sensor
}

\author{
Yuda Irawan ${ }^{1}$, Anita Febriani ${ }^{2}$, Refni Wahyuni ${ }^{3}$, Yesica Devis ${ }^{4}$ \\ ${ }^{1}$ Department of Information System, STMIK Hang Tuah Pekanbaru, Pekanbaru, Indonesia \\ ${ }^{2,3}$ Department of Computer Science, STMIK Hang Tuah Pekanbaru, Pekanbaru, Indonesia \\ ${ }^{4}$ Department of Public Health, STIKes Hang Tuah Pekanbaru, Pekanbaru, Indonesia \\ Email: ${ }^{1}$ yudairawan89@gmail.com, ${ }^{2}$ nitasuheri@gmail.com, ${ }^{3}$ refniabid@ gmail.com, ${ }^{4}$ \\ jejes.devis@gmail.com
}

\begin{abstract}
Rusunawa Rejosari is a flats owned by the Pekanbaru city government which is inhabited by underprivileged residents, water in the Rusunawa Rejosari borehole emits an unpleasant and murky odor, making it unfit for consumption and use for daily needs by residents who live there. Indonesia issued the TDS Standard by the Ministry of Health and the Indonesian National Standard (SNI), which is a maximum value of $500 \mathrm{ppm}$ TDS and for the standard Hydrogen Potential (PH) of clean water 6.6 - 9.0 PH. Based on the above problems, a Water Quality Measurement and Filtration Tool was made using Arduino, a Hydrogen Potential Sensor (PH) and a Total Dissolved Solids (TDS) Sensor. Based on the research that has been carried out, it can be concluded that the tool runs smoothly, as evidenced by the measurement results of the accuracy of the sensor and successfully filters the water when the measurement is not normal, so that the water is suitable for consumption and use.
\end{abstract}

Keywords-Arduino Uno, PH Sensor, TDS Sensor Meter, Quality of Water.

\section{INTRODUCTION}

Rusunawa Rejosari is a flat owned by the local government which is located on Jalan. Kampung Baru, Kelurahan. Bambu Kuning District. Tenayan Raya Pekanbaru City. Where Rusunawa Rejosari is inhabited by underprivileged residents. The author observes the water sources in the drilled wells in Rusunawa Rejosari for one month, the water in the wells emits an unpleasant and cloudy odor, so it is not suitable for consumption and is used as daily necessities by residents living in Rusunawa Rejosari. There are two control valves: control valve 1 opens the water flow without passing through the filter and control valve 2 will open the water flow to the filter if the sensor shows an abnormal measurement number was studied by vanmathi [1].

However, drilled well water is not always cloudy, sometimes the water can become clean depending on the water discharge in the well was studied by moparthi [2]. When the water is cloudy and smells bad, the residents of Rusunawa Rejosari prefer to use water from the Drinking Water Company instead of using drilled well water, thus increasing the costs that are quite large if it is borne by the less fortunate was studied by wang [3].

According to the World Health Organization (WHO), the standard for purity of drinking water is a TDS level below
100 ppm was studied by Raghavan [4]. Good water has a TDS level of less than 300-600 ppm (Part Per Million), which has relatively small mineral components such as calcium and magnesium was studied by Arvind [5]. If water has a TDS level of 900-1200 ppm (Part Per Million) or more, it means that the water has a relatively large mineral content and is dangerous for health was studied by pant [6].

Indonesia also issued TDS Standards by the Ministry of Health of the Republic of Indonesia and Indonesian National Standards (SNI), namely the maximum TDS value of 500 ppm was studied by layanaya [7] and irawan [8]. Because Rusunawa Rejosari is located in Indonesia, it is better if it refers to the standards of the Ministry of Health of the Republic of Indonesia and Indonesian National Standards was studied by defe [9]. And for the Potential Hydrogen (PH) standard of clean water from the Government Health Regulation 416 / Minister of Health / Per / IX / 1990 is 6.6 9.0 PH was studied by faricha [10].

Based on previous research by suhaimi [11] Measuring Drinking Water Quality with Potential Parameters of Hydrogen (PH), Temperature, Turbidity Level, and Total Dissolved Solids, where the application of a tool designed to measure the cleanliness of mineral drinking water only was studied by singh [12].

With the author's sense of concern and based on previous research, the author will design and implement a tool for measuring the quality and filtering of water at the Rejosari Rusunawa Drilling Well, so that the drilled well water can be consumed and used for daily needs by residents who live there and their health is guaranteed as well. avoid diseases such as diarrhea, nausea and itching of the skin was studied by ordila [13].

Based on the explanation above, the author is interested in raising the research topic in the form of prototype simulation, and the title of the research, namely "Water Quality Measurement and Filtering Tools Using Arduino, Hydrogen Potential Sensor (PH) and Total Dissolved Solids (TDS) Meter Sensor (Case Study: Drilling Well Rusunawa Rejosari Pekanbaru) " was studied by nandakumar [14].

\section{METHODS}

\section{A. Requirements Definition}


Here the researcher performs complete data collection then performs an analysis and defines the needs that will be used for system development was studied by sohor [15]. This is a very important part because the system to be created will interact directly with important elements in computers such as hardware and software was studied by irawan [16].

\section{B. Design}

In this stage, the researcher describes the design of the technology that will be built in accordance with the data analysis carried out in the previous stage was studied by surendran [17].

\section{Encoding}

The program design in the previous stage was translated into codes using a programming language. In this system, the programming language used is $\mathrm{C}$ and Pascal was studied by wang [18].

\section{Testing}

In this stage, the modules of the water quality measuring equipment that have been made are combined and tested to find out whether the system that has been built is in accordance with the design and whether there are still errors or not. Testing using the Black Box is testing carried out directly by the User was studied by Lakshmanan [19].

\section{E. Maintenance}

This is the last stage where a tool that has been designed will be treated and maintained.

\section{IMPLEMENTATION}

In general, the system block diagram in the design can be seen in the Figure 1

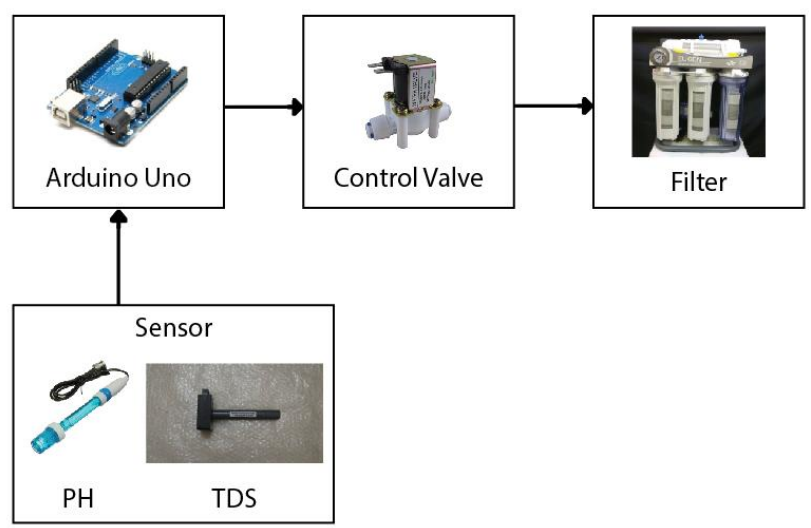

Fig. 1. Block Diagram System

The working principle of this tool is to use 2 types of sensors. These sensors consist of a $\mathrm{pH}$ sensor for measuring acid or base levels and a TDS sensor for measuring TDS in water.

The sensors are then connected to the Arduino Uno controller circuit. The sensor data will then be sent to the control valve in the form of a 12-volt electric voltage to move the control valve to open the water channel.

\section{A. Hardware (Hardware)}

1. Fiberglass, as the main material in making tool boxes
2. $\mathrm{pH}$ sensor (Analog $\mathrm{pH}$ Sensor), serves to detect the level of acidity or alkalinity in water

3. The TDS sensor is used to detect the number of dissolved solid particles in water, both organic and inorganic or commonly called Total Dissolved Solids

4. Arduino Uno functions as the control center of the entire system work

5. Filter as a means of filtering cloudy and smelly water

\section{B. System Design}

The design of the TDS and $\mathrm{pH}$ measuring instrument system includes the design of hardware (Hardware) and software (Software).

\section{Hardware Design (Hardware)}

This hardware design includes designing input and output circuits that are connected to a microcontroller circuit. The input circuit includes a TDS sensor and a $\mathrm{pH}$ sensor. Meanwhile, the output circuit is a control valve which functions to open the water flow to the filter.

\section{Arduino Uno circuit}

The microcontroller circuit used is the Arduino Uno R3 circuit board based on the AVR ATMega 328P chip. Arduino Uno has 14 digital input / output pins (of which 6 pins can be used as PWM outputs), 6 analog input pins, using a $16 \mathrm{MHz}$ crystal, a USB connection, a power jack, an ICSP header and a reset button.

TABLE I. PIN DESCRIPTION OF ARDUINO UNO R3

\begin{tabular}{|c|c|}
\hline Arduino Pin & Utilization \\
\hline $5 \mathrm{~V}$ & Power supply circuit \\
\hline GND & Ground \\
\hline A0 & pH Sensor \\
\hline A1 & TDS Sensor \\
\hline $12 \mathrm{~V}$ & $\begin{array}{c}\text { Solenoid Valve (Control } \\
\text { Valve) } 1\end{array}$ \\
\hline $12 \mathrm{~V}$ & $\begin{array}{c}\text { Solenoid Valve (Control } \\
\text { Valve) } 2\end{array}$ \\
\hline
\end{tabular}

\section{E. Input Circuits}

1) TDS sensor

The TDS sensor uses the Electrical Conductivity method, where two probes are immersed in a liquid or solution then a signal processing circuit will produce an output that shows the conductivity of the solution. This sensor has 3 pins, namely the DATA, VCC and GND pins. The DATA pin is connected to the Arduino analog pin (A0) while VCC is connected to the regulator output pin and GND is connected to the regulator ground pin.

\section{2) b. PH sensor}

The $\mathrm{pH}$ sensor is based on the electro-chemical potential difference that occurs between the known solution inside the electrode and the unknown solution outside the electrode. This sensor has a glass electrode with a round tip. There are 3 pins on the sensor, namely the DATA, VCC and GND pins. The DATA pin is connected to the Arduino analog pin (A2), 
VCC is connected to the regulator output pin and GND is connected to the regulator ground pin.

\section{F. Output Circuit}

The output circuit in the system is a 12 -volt control valve. There are two control valves in this system, control valve 1 will open the water flow without passing through the filter if the sensor shows the water quality is suitable for use and control valve 2 will open the water flow to the filter if the TDS sensor and $\mathrm{pH}$ sensor show a measurement number that exceeds normal limits. than has been set.

\section{1) TDS Sensor Testing}

This test is conducted to determine the response of the TDS sensor to changes in TDS in water. The response of the sensor in question is the value of the sensor voltage to TDS (ppm). The sensor is first connected to the Arduino Uno so that it can display the analog value and sensor voltage via the Arduino IDE monitor serial. Meanwhile, the measuring instrument used to determine TDS in water is TDS Meter 3. In the test, 5 types of liquids were used with different TDS values. The liquid is made from water added with salt at different doses, then the TDS of the liquid is measured using a TDS Meter 3. The test results are as follows:

TABLE 2. TDS SENSOR TEST RESULTS

\begin{tabular}{|c|c|}
\hline TDS Water (ppm) & Sensor Voltage (Volt) \\
\hline 130 & 1.02 \\
\hline 166 & 1.13 \\
\hline 202 & 1.22 \\
\hline 242 & 1.41 \\
\hline 284 & 1.6 \\
\hline 325 & 1.72 \\
\hline 356 & 1.83 \\
\hline 401 & 1.98 \\
\hline
\end{tabular}

\section{2) PH Sensor Testing}

This test is conducted to determine the accuracy of the sensor. The value generated by the sensor will then be compared with the value from the measuring instrument. The $\mathrm{pH}$ measuring instrument used is the Orion $\mathrm{pH} /$ ISE meter model 710A. Whereas for the sample tested was the leaf extract added with $\mathrm{HCl}$ solution.

TABLE 3. PH SENSOR TEST RESUlts

\begin{tabular}{|c|c|c|c|c|}
\hline $\begin{array}{l}\text { Material } \\
\text { Code }\end{array}$ & $\begin{array}{c}\text { PH } \\
\text { sensor }\end{array}$ & $\begin{array}{c}\text { Average } \\
\text { Sensor }\end{array}$ & $\begin{array}{c}\mathrm{PH} \\
\text { meter }\end{array}$ & $\begin{array}{c}\text { Percentage of } \\
\text { Error (\%) }\end{array}$ \\
\hline Aquades & 5.511 & 5.511 & 5.509 & 0.04 \\
\hline 更 & $\begin{array}{l}0.694 \\
0.694 \\
0.693 \\
0.694 \\
0.694 \\
0.693 \\
0.694 \\
0.694\end{array}$ & 0.6937 & 0,698 & 0.43 \\
\hline
\end{tabular}

\begin{tabular}{|c|c|c|c|c|}
\hline & $\begin{array}{l}0.693 \\
0.694\end{array}$ & & & \\
\hline $\mathrm{KOPIKH}_{3}$ & $\begin{array}{l}0.683 \\
0.682 \\
0.682 \\
0.682 \\
0.682 \\
0.682 \\
0.683 \\
0.682 \\
0.682 \\
0.682\end{array}$ & 0.6822 & 0.671 & 1.67 \\
\hline $\mathrm{NYAKH}_{1}$ & $\begin{array}{l}0.662 \\
0.662 \\
0.661 \\
0.661 \\
0.662 \\
0.661 \\
0.662 \\
0.662 \\
0.661 \\
0.662\end{array}$ & 0.6616 & 0.663 & 0.21 \\
\hline $\mathrm{NYAKH}_{2}$ & $\begin{array}{l}0.618 \\
0.617 \\
0.617 \\
0.617 \\
0.618 \\
0.618 \\
0.617 \\
0.617 \\
0.617 \\
0.617\end{array}$ & 0.6173 & 0.62 & 0.44 \\
\hline \multicolumn{4}{|c|}{ Average Percentage of Error } & 0.58 \\
\hline
\end{tabular}

\section{3) Solenoid Valve Testing}

This test is conducted to determine whether the solenoid valve can function properly in opening the water channel. Water with normal measurements will be flowed directly by opening the solenoid valve 1 , while the water that is not feasible or the measurement results from the sensors is abnormal, will flow into the filter by opening the solenoid valve 2 . The solenoid valve will work if you get a voltage of 12 volts from Arduino Uno.

\section{G. Overall Tool Testing}

This test aims to determine whether the system as a whole has worked in accordance with the design. The overall test was carried out by taking water from the borehole well in Rusunawa Rejosari Pekanbaru, carried out 5 times by taking water samples with an interval of 3 days for 15 days, this was 
done so that there was a change in water quality in the well, so that when testing there were 5 samples with water quality varies.

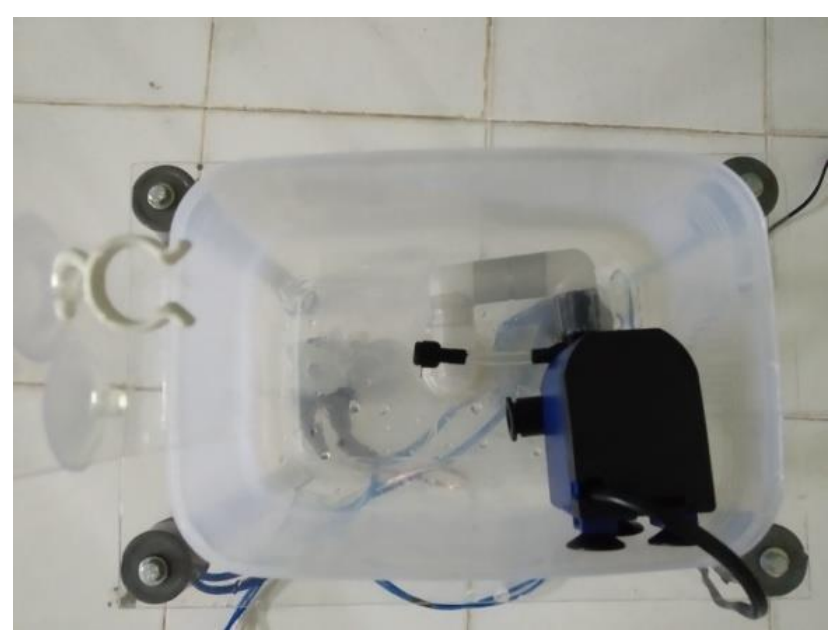

Fig. 2. Water Storage Containers

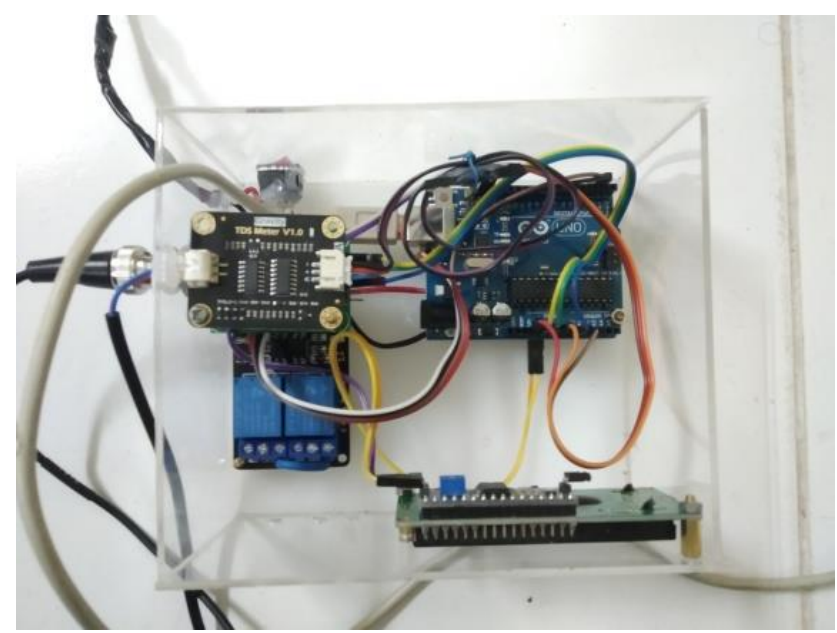

Fig. 3. Arduino circuit

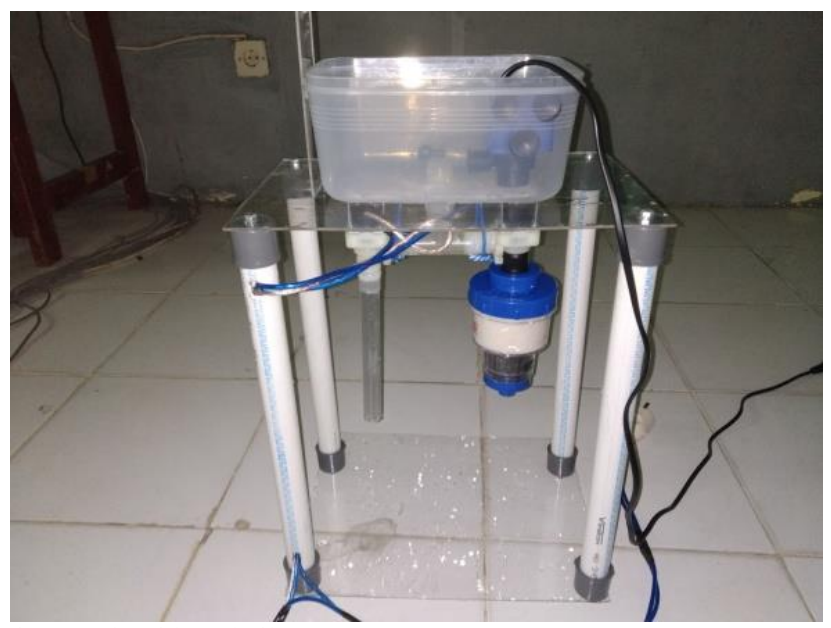

Fig. 4. Solenoids and Filters

From 5 water samples will then be tested with the tools that have been made. The results of water sample measurements are as follows:

TABle 4. WATER SAMPLE MEASUREMENT Results

\begin{tabular}{|c|c|c|c|}
\hline Sampel & $\begin{array}{c}\text { TDS } \\
(\mathbf{p p m})\end{array}$ & $\begin{array}{c}\text { Turbidity } \\
\text { (NTU) }\end{array}$ & $\mathbf{p H}$ \\
\hline 1 & 184 & 93.34 & 8.326 \\
\hline 2 & 177 & 38.49 & 8.214 \\
\hline 3 & 198 & 17 & 8.865 \\
\hline 4 & 174 & 82.92 & 8.895 \\
\hline 5 & 213 & 120.69 & 8.913 \\
\hline Average & $\mathbf{1 8 9 . 2}$ & $\mathbf{7 0 . 4 8 8}$ & $\mathbf{8 . 6 4 2 6}$ \\
\hline
\end{tabular}

The comparison of the results of the TDS, turbidity and $\mathrm{pH}$ parameters obtained with the requirements for clean water quality is based on the Minister of Health Regulation Number: 416 / MEN.KES / PER / IX / 1990 as follows:

TABLE 5. COMPARISON OF TDS FOR DRILLING WeLl WATER WITH CLEAN

\begin{tabular}{|c|c|c|c|}
\hline & $\begin{array}{c}\text { WATER QUALITY REQUIREMENTS } \\
\text { Sampel } \\
(\mathbf{p p m})\end{array}$ & $\begin{array}{c}\text { Maximum } \\
\text { permissible } \\
\text { level (ppm) }\end{array}$ & Information \\
\hline 1 & 184 & 1000 & Qualify \\
\hline 2 & 177 & 1000 & Qualify \\
\hline 3 & 198 & 1000 & Qualify \\
\hline 4 & 174 & 1000 & Qualify \\
\hline 5 & 213 & 1000 & Qualify \\
\hline
\end{tabular}

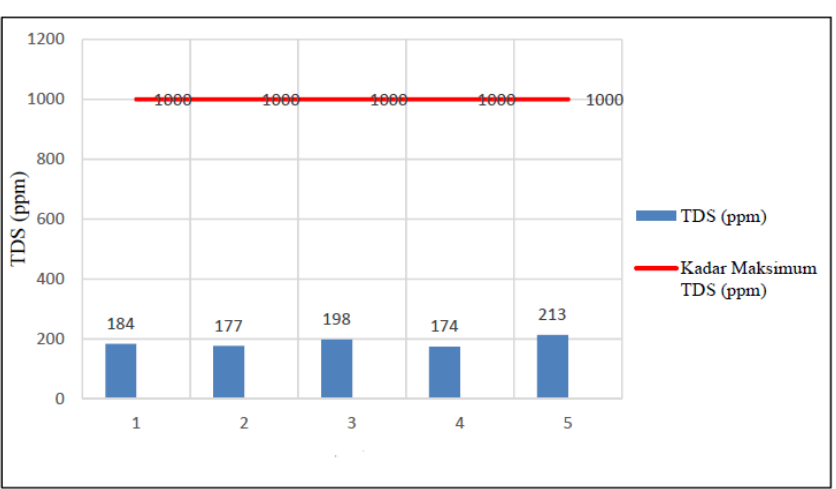

Fig. 5. Graph of TDS Test Results

From the test results, it can be seen that the TDS of the Rusunawa Rejosari borehole water meets the requirements for clean water based on the Minister of Health Regulation Number: 416 / MEN. KES / PER / IX / 1990 is still below the maximum allowable level (1000 ppm).

TABLE 6. COMPARISON OF THE TURBIDITY OF RUSUNAWA REJOSARI WELL WATER WITH CLEAN WATER QUALITY REQUIREMENTS

\begin{tabular}{|c|c|c|c|}
\hline Sample & $\begin{array}{c}\text { Turbidity } \\
\text { (NTU) }\end{array}$ & $\begin{array}{c}\text { Maximum } \\
\text { permissible } \\
\text { level (NTU) }\end{array}$ & Information \\
\hline 1 & 93.34 & 25 & Not eligible \\
\hline 2 & 38.49 & 25 & Not eligible \\
\hline 3 & 17 & 25 & Not eligible \\
\hline 4 & 82.92 & 25 & Not eligible \\
\hline
\end{tabular}




\begin{tabular}{|l|l|l|l|}
5 & 120.69 & 25 & Not eligible \\
\hline
\end{tabular}

From the test results, it can be seen that the turbidity of the Rusunawa Rejosari borehole water does not meet the clean water requirements based on the Minister of Health Regulation Number: 416 / MEN.KES / PER / IX / 1990 because it has passed the maximum allowable level (25 NTU).

TABle 7. COMPARISON OF DRILLING WELl WATER PH WITH CLEAN

\begin{tabular}{|c|c|c|c|}
\hline \multirow{2}{*}{ Sample } & $\begin{array}{c}\text { Turbidity } \\
\text { (NTU) }\end{array}$ & $\begin{array}{c}\text { Maximum } \\
\text { permissible } \\
\text { level }\end{array}$ & Information \\
\hline 1 & 8.326 & $6.5-9$ & Eligible \\
\hline 2 & 8.214 & $6.5-9$ & Eligible \\
\hline 3 & 8.865 & $6.5-9$ & Eligible \\
\hline 4 & 8.895 & $6.5-9$ & Eligible \\
\hline 5 & 8.913 & $6.5-9$ & Eligible \\
\hline
\end{tabular}

From the test results, it can be seen that the $\mathrm{pH}$ of the Rusunawa Rejosari borehole water still meets the clean water requirements based on the Minister of Health Regulation Number: 416 / MEN.KES / PER / IX / 1990 because it is still between the maximum and minimum levels allowed (6.5 - 9).

TABle 8. WATER MEASUREMENT Results After PASSING THE FilteR

\begin{tabular}{|c|c|c|c|}
\hline Sample & $\begin{array}{c}\text { TDS } \\
(\mathbf{p p m})\end{array}$ & $\begin{array}{c}\text { Turbidity } \\
\text { (NTU) }\end{array}$ & $\mathbf{p H}$ \\
\hline 1 & 180 & 15.5 & 7.257 \\
\hline 2 & 174 & 15.4 & 7.152 \\
\hline 3 & 195 & 15.7 & 7.558 \\
\hline 4 & 171 & 15.5 & 8.252 \\
\hline 5 & 212 & 15.8 & 8.336 \\
\hline Average & $\mathbf{1 8 6 . 4}$ & $\mathbf{1 5 . 5 8}$ & $\mathbf{7 . 7 1 1}$ \\
\hline
\end{tabular}

\section{H. Analysis of Test Results}

From the results of the overall tool testing as shown in Table VII, it can be concluded that the tool has worked in measuring the TDS, turbidity and $\mathrm{pH}$ of the Rusunawa Rejosari borehole water. The results of water measurements from 5 samples after using the tool showed the TDS ranged from $171 \mathrm{ppm}$ to $212 \mathrm{ppm}$ with an average of $186.4 \mathrm{ppm}$ and a $\mathrm{pH}$ ranging from 7,152 to 8.336 with an average of 7,711. Based on the Regulation of the Minister of Health Number: 416 / MEN.KES / PER / IX / 1990 concerning clean water quality requirements which requires a maximum TDS value of 1,000 mg / 1 or ppm and a $\mathrm{pH}$ of 6.5-9.0 for maximum and minimum limits. So it can be concluded that the TDS and $\mathrm{pH}$ of the Rusunawa Rejosari borehole water after using an Arduino, a pH sensor and a TDS meter sensor, have met the maximum permissible level requirements, are fit for consumption and used for daily needs.

\section{CONCLUSION}

Based on the test results, several conclusions can be drawn, including the following: With a device built and designed to measure water quality, it will be possible to know how much the value of the PH and TDS content in the water of the Rusunawa Rejosari borehole, which aims for people living there knowing whether the well water is suitable for consumption and use for daily needs with a large content of $\mathrm{PH}$ value and large TDS value in Rusunawa Rejosari well water.

Based on the regulations of the Government of Health of the Republic of Indonesia and the Indonesian National Standard (SNI), for water quality, the standard value of $\mathrm{PH}$ is $6.5-9.0$, and the maximum value of TDS is 500 ppm (Part Per Million).

\section{REFERENCES}

[1] C. Vanmathi, R. Mangayarkarasi and J. Subalakshmi R., "Real Time Weather Monitoring using Internet of Things," 2020 International Conference on Emerging Trends in Information Technology and Engineering (ic-ETITE), Vellore, India, 2020, pp. 1-6, doi: 10.1109/ic-ETITE47903.2020.348.

[2] N. R. Moparthi, C. Mukesh and P. Vidya Sagar, "Water Quality Monitoring System Using IOT," 2018 Fourth International Conference on Advances in Electrical, Electronics, Information, Communication and Bio-Informatics (AEEICB), Chennai, 2018, pp. 1-5, doi: 10.1109/AEEICB.2018.8480963.

[3] Y. Wang et al., "Integrating Open-Source Technologies to Build a School Indoor Air Quality Monitoring Box (SKOMOBO)," 2017 4th Asia-Pacific World Congress on Computer Science and Engineering (APWC on CSE), Nadi, 2017, pp. 216-223, doi: 10.1109/APWConCSE.2017.00046.

[4] S. S. Raghavan, V. Loganathan, V. Rathod and G. S. Sharvani, "Cloud Enabled Water Contamination Detection System," 2017 2nd International Conference on Computational Systems and Information Technology for Sustainable Solution (CSITSS), Bangalore, 2017, pp. 1-4, doi: 10.1109/CSITSS.2017.8447569.

[5] A. Arvind, R. Paul and P. Bhulania, "Implementation of Water Quality Sensing System using Internet of Things," 2020 7th International Conference on Signal Processing and Integrated Networks (SPIN), Noida, India, 2020, pp. 1025-1028, doi: 10.1109/SPIN48934.2020.9070832.

[6] D. Pant, A. Bhatt, M. Khan, O. P. Nautiyal and P. Adhikari, "Automated IoT based Smart Water Quality Assessment System," 2019 8th International Conference System Modeling and Advancement in Research Trends (SMART), Moradabad, India, 2019, pp. 98-104, doi: 10.1109/SMART46866.2019.9117271.

[7] M. Lavanaya and R. Parameswari, "Soil Nutrients Monitoring For Greenhouse Yield Enhancement Using $\mathrm{Ph}$ Value with Iot and Wireless Sensor Network," 2018 Second International Conference on Green Computing and Internet of Things (ICGCIoT), Bangalore, India, 2018, pp. 547-552, doi: 10.1109/ICGCIoT.2018.8753083.

[8] Irawan, Y., Fernando, Y., \& Wahyuni, R. Detecting Heart Rate Using Pulse Sensor As Alternative Knowing Heart Condition. Journal of Applied Engineering and Technological Science (JAETS),2019, 1(1), pp 30-42.

[9] G. A. Defe and A. Z. C. Antonio, "Multi-parameter Water Quality Monitoring Device for Grouper Aquaculture," 2018 IEEE 10th International Conference on Humanoid, Nanotechnology, Information Technology,Communication and Control, Environment and Management (HNICEM), Baguio City, Philippines, 2018, pp. 15, doi: 10.1109/HNICEM.2018.8666414.

[10] A. Faricha et al., "Water Monitoring Prototype Using Internet of Things Technology," 2019 International Conference on Advanced Mechatronics, Intelligent Manufacture and Industrial Automation (ICAMIMIA), Batu, Malang, Indonesia, 2019, pp. 141-144, doi: 10.1109/ICAMIMIA47173.2019.9223380.

[11] K. M. Ng, M. A. Haziq Mohd Suhaimi, A. Ahmad and N. A. Razak, "Remote Air Quality Monitoring System by Using MyRIOLabVIEW," 2018 9th IEEE Control and System Graduate Research Colloquium (ICSGRC), Shah Alam, Malaysia, 2018, pp. 105-109, doi: 10.1109/ICSGRC.2018.8657501.

[12] P. Singh and S. Saikia, "Arduino-based smart irrigation using water flow sensor, soil moisture sensor, temperature sensor and ESP8266 WiFi module," 2016 IEEE Region 10 Humanitarian Technology 
Conference (R10-HTC), Agra, 2016, pp. 1-4, doi: 10.1109/R10HTC.2016.7906792.

[13] Ordila, Rian, et al. Penerapan Alat Kendali Kipas Angin Menggunakan Microcontroller Arduino Mega 2560 Dan Sensor Dht22 Berbasis Android. Riau Journal Of Computer Science, 2020, 6.2: 101-106.

[14] L. Nandakumar, M. Sangeeth, M. Anna Mariya Thomson, A. Tommy, M. P. Kiran and P. Raji, "Real Time Water Contamination Monitor using Cloud, IoT and Embedded Platforms," 2020 International Conference on Smart Electronics and Communication (ICOSEC), Trichy, India, 2020, pp. 854-858, doi: 10.1109/ICOSEC49089.2020.9215276.

[15] Sohor, Suherman, Et Al. Rancang Bangun Tempat Sampah Otomatis Mengunakan Mikrokontroler Dan Sensor Ultasonik Dengan Notifikasi Telegram. Jurnal Ilmu Komputer, 2020, 9.2: 154-160.

[16] Irawan, Yuda. Aplikasi Android Sebagai Media Pembelajaran Organ Tubuh Manusia Dengan Menerapkan Augmented Reality (Studi
Kasus: Sdn 005 Makmur Pangkalan Kerinci). Jurnal Ilmu Komputer, 2020, 9.2: 102-106.

[17] G. Surendran, G. Udupa and G. J. Nair, "Design and modelling of cable suspended sonde for water quality monitoring," 2017 International Conference on Intelligent Computing, Instrumentation and Control Technologies (ICICICT), Kannur, 2017, pp. 1260-1265, doi: 10.1109/ICICICT1.2017.8342750.

[18] Y. Wang et al., "Deployment issues for integrated open-source Based indoor air quality school Monitoring Box (SKOMOBO)," 2018 IEEE Sensors Applications Symposium (SAS), Seoul, 2018, pp. 1-4, doi: 10.1109/SAS.2018.8336758.

[19] L. Lakshmanan, A. Jesudoss, A. Sivasangari, S. Maran and M. Mercy Theresa, "Analysis of the Water Quality Monitoring System," 2020 International Conference on Communication and Signal Processing (ICCSP), Chennai, India, 2020, pp. 1032-1035, doi: 10.1109/ICCSP48568.2020.9182256. 